\title{
THE FAILURE OF "TRUTH AND CLARITY" AT BERNE: KURT EISNER, THE OPPOSITION AND THE RECONSTRUCTION OF THE INTERNATIONAL
}

To better understand why Marxist Internationalism took on the forms that it did during the revolutionary epoch that followed World War I, it is useful to reconsider the "International Labor and Socialist Conference" that met at Berne from January 26 to February 10, 1919. This gathering not only set its mark on the "reconstruction" of the Second International, it also influenced both the formation and the development of the Communist International. It is difficult, however, to comprehend fully what transpired at Berne unless the crucial role taken in the deliberations by Kurt Eisner, on the one hand, and the Zimmerwaldian Opposition, on the other, is recognized. To a much greater extent than has generally been realized, the immediate success and the ultimate failure of the Conference depended on the Bavarian Minister President and the loosely structured opposition group to his Left. Nevertheless every scholarly study of the Conference to date, including Arno Mayer's excellent treatment of the "Stillborn Berne Conference", tends to underestimate Eisner's impact while largely ignoring the very existence of the Zimmerwaldian Opposition. ${ }^{1}$ Yet, if these two elements are neglected it becomes extremely difficult, if not impossible, to fathom the real significance of Berne. Consequently there is a need to reevaluate

1 In Mayer's case this would seem to be related to two factors: first, the context in which he examines Berne, namely the attempt by Allied labor leaders to influence the Paris Peace Conference; and second, his reliance on English and French accounts of the Conference. See Arno J. Mayer, Politics and Diplomacy of Peacemaking. Containment and Counterrevolution at Versailles, 1918-1919 (New York, 1967), pp. 373-409. For other accounts of the Berne Conference see: Julius Braunthal, History of the International, II (New York, 1967), pp. 149-156; G. D. H. Cole, A History of Socialist Thought, IV/I (London, 1958), pp. 290-299; Merle Fainsod, International Socialism and the World War (Cambridge, 1935), pp. 249-257; Lewis L. Lorwin, Labor and Internationalism (New York, 1929), pp. 166-168; and Austin van der Slice, International Labor, Diplomacy and Peace, 1914-1919 (Philadelphia, 1941), pp. 309-333. This last work probably contains, after Mayer's, the most thoughtful analytical treatment of the Conference. 
Eisner's role in the proceedings, particularly his behind the scenes activities, as well as to consider the attempt to resurrect the Zimmerwaldian movement during the Conference. In no small way the responsibility for the fateful decisions taken at Berne, decisions which ultimately proved detrimental to the cause of the International, lies with the hyperactive Kurt Eisner and the relatively passive Zimmerwaldian Opposition.

If Eisner's actions at Berne have not been entirely ignored, attention has commonly focused on those public remarks which brought him notoriety in Germany, specifically his assertion of Imperial Germany's responsibility for the war and especially his alleged comments concerning prisoners of war. ${ }^{1}$ This is understandable considering the press campaign waged against Eisner for these "traitorous" remarks, attacks which, it has been suggested, were largely responsible for his assassination a short time later. ${ }^{2}$ Unfortunately this has seemingly led to a tendency to focus on the "humanitarian spirit" and "idealism" Eisner exhibited at Berne while ignoring his important, and conscious, practical role in helping the Conference deal with some of its most difficult problems. ${ }^{3}$ In reality the very fact that the International Conference was able to consider the questions of "war responsibility" and "democracy and dictatorship" without breaking up was in no small way due to the work of Kurt Eisner. Ironically Eisner, an Independent Social Democrat (USPD), was not even delegated by his party to attend the Berne Conference ${ }^{4}$ nor did he prove particularly representative of

1 Felix Fechenbach, Der Revolutionär Kurt Eisner (Berlin, 1929), pp. 56-60; Ernst Niekisch, Gewagtes Leben. Begegnungen und Begebnisse (Cologne, 1958), pp. 49-50; Franz Schade, Kurt Eisner und die bayerische Sozialdemokratie (Hannover, 1961), pp. 84 and 163.

2 Ernst Toller, Eine Jugend in Deutschland (Hamburg, 1963), p. 84; Hans Beyer, Von der Novemberrevolution zur Räterepublik in München (Berlin, 1957), pp. 37, 39; Fechenbach, Eisner, p. 61 ; Niekisch, Gewagtes Leben, p. 50 ; Freiheit, No 94, February 21, 1919. Eight days before his assassination Eisner read publicly the contents of a student handbill accusing him of opposing the release of German prisoners of war and urging his murder. See Extranummer der Neuen Zeitung, n.d. (February 14-15, 1919) (hereafter cited as Extranummer).

3 See, for example, Mayer, Politics and Diplomacy, p. 391 ; Robert Michels, "Kurt Eisner", in: Archiv für die Geschichte des Sozialismus und der Arbeiterbewegung, XIV, pp. 378, 382. Invariably any recognition of a practical side to Eisner's activity at Berne has been confined to pointing out how he actually helped the German cause by his statements during the Conference.

4 Nevertheless once Eisner arrived in Berne, he was quickly coopted by the official USPD delegation and with the early departure of Hugo Haase, he became, despite the presence of Karl Kautsky, the Independents' chief spokesman at the Conference. What initially prompted Eisner to go to Berne is not completely clear. Alan Mitchell, Revolution in Bavaria 1918-1919 (Princeton, 
USPD sentiment on the International. ${ }^{1}$ If in the short run this was probably to the Conference's advantage, in the long run it was to prove most unfortunate for the International.

The one Independent Social Democrat present in Berne who was fairly representative of opinion within his party was Josef Herzfeld. Sent to the Conference by the tiny USPD organization in Mecklenburg, Herzfeld had been an active participant in the Zimmerwald movement during the war. ${ }^{2}$ Yet he failed to exert any influence on his party's official delegation and was even prevented from addressing the Conference, allegedly at Karl Kautsky's insistence. ${ }^{3}$ What Herzfeld did do was to cooperate with the Zimmerwaldian Opposition, a loose grouping of delegates and observers who objected to the right-wing, "socialpatriotic" tenor of the Berne Conference. ${ }^{4}$ Paradoxically it was the leadership of the Swiss Social Democratic Party (SPS), which only a few months earlier had blocked an attempt to call a fourth Zimmerwald conference, ${ }^{5}$ that now took the lead in trying to organize the Opposition.

$1965)$, p. 255 , has suggested that his purpose was to "revive the mystique of the first days of his regime" but without documenting this hypothesis. One thing is certain, the German foreign office was strongly opposed to Eisner's decision and attempted unsuccessfully to block his attendance. See telegram from Adolf Müller, Ambassador at Berne, to the Foreign Office on January 23, and further the telegram of Zech, Munich, to the Foreign Office on January 25, Politisches Archiv des Auswärtigen Amtes, Weltkrieg 2c, Die Sozialisten-Konferenzen, XIII. ${ }^{1}$ For an examination of Independent Social Democratic attitudes towards the Berne Conference see the author's doctoral dissertation, "The Independent Social Democratic Party and the Internationals: An Examination of Socialist Internationalism in Germany 1915-1923" (University of Pittsburgh, 1970), pp. 145-155, 188-195.

2 Herzfeld had attended the Zimmerwald Conference but had been prevented by the German police from attending any further meetings in Switzerland during the war. See Horst Lademacher, ed., Die Zimmerwalder Bewegung. Protokolle und Korrespondenz (The Hague, 1967), I, pp. 45 and 273; Deutsches Zentralarchiv Potsdam, Reichstag No 1704 Kommissionsverhandlung, pp. 633-635. 3 Unabhängige Sozialdemokratische Partei Deutschlands, Protokoll über die Verhandlungen des ausserordentlichen Parteitages vom 2. bis 6. März 1919 in Berlin (Berlin, n.d.) (hereafter cited as USPD, Protokoll-Berlin), p. 189.

4 Unfortunately the only published account of the activities and composition of the Opposition is contained in Fritz Platten's speech before the founding Congress of the Communist International. See Der I. Kongress der Kommunistischen Internationale. Protokoll der Verhandlungen in Moskau vom 2. bis zum 19. März 1919 (Hamburg, 1921), pp. 150-151.

s Speaking at Berne on October 30,1918 before a meeting of the Swiss Social Democratic Party's Geschäftsleitung, Angelica Balabanova, Secretary of the International Socialist Commission, urged that a Zimmerwald conference be called as soon as possible. Only Fritz Platten, however, supported her and against his vote the Geschäftsleitung rejected this suggestion. When a similar 
This about-face was related to the fact that on February 2 a special SPS national congress voted overwhelmingly against participating in the Berne Conference while calling for the union of all Zimmerwaldian groups. ${ }^{1}$ Consistent with this position, the Swiss attempted to convince all Zimmerwaldians present at Berne to boycott the Conference and proposed to convene instead a special gathering of their own in order to discuss the establishment of "new organizations [...] in the International". Both these proposals, however, were rejected by an ad hoc meeting of the Opposition held in early February. This was not surprising given the heavy representation of the French Majority Socialists at this gathering since the French had previously criticized the Bolsheviks, Spartacists and the SPS for not attending the Conference, arguing that their presence would enable the International to clean house. More unexpectedly, perhaps, a majority of the Opposition was also unwilling to accept as an alternative the Swiss suggestion that the Zimmerwaldians attending the Conference adopt a common plan of action and counter all official Conference resolutions with proposals of their own. Apparently all they could agree upon at this point was to remain in contact with one another and to participate in a public rally organized by the Swiss. Despite their purported desire to "clean house" most of the Opposition were not initially willing to risk the unity of their nationnal delegations or the Conference itself by concerted action. ${ }^{2}$ Conceivably this hesitation to force the issue was also related to their minority position at Berne.

Kurt Eisner presents an interesting contrast. Although he met privately with individual members of the Opposition, Eisner never attended an Opposition caucus even though his party had participated in the

proposal calling on the Swiss to organize a meeting of Zimmerwaldian parties was placed before the SPS Parteivorstand on December 20, it was rejected in turn. (At this same Parteivorstand meeting the Swiss also refused to consider the possibility of their calling a general conference of the International.) See the report of the German military attaché at Berne, dated November 4, 1918, Politisches Archiv des Auswärtigen Amtes, Gesandtschaft Bern 17/160 Bolschewismus in der Schweiz, I ; Sozialdemokratische Partei der Schweiz, Geschäftsbericht für die Jahre 1918 bis 1920 (Zurich, 1921), p. 48.

1 The vote was 238 to 147 . See Berner Tagwacht, No 27, February 3, 1919, and SPS, Geschäftsbericht, op. cit., p. 49.

2 See Fritz Platten's account, ibid. Among those in attendance at this meeting arranged by Platten and Robert Grimm (SPS) were Friedrich Adler (Austria), Petrov (Russia), Paul Faure, L.-O. Frossard, Fernand Loriot, Charles Rappoport, and Raoul Verfeuil (France), Oddino Morgari (Italy), Burian (Czechoslovakia), Olav Scheflo (Norway), Julian Besteiro (Spain), Martna (Estonia) and Herzfeld (USPD). Of these only Morgari and Loriot supported the initial Swiss proposal. 
Zimmerwald movement. ${ }^{1}$ Moreover where the Opposition hesitated to act out of concern for unity, he acted in order to insure unity. Essentially, Eisner's activities at Berne suggest that he saw his role as that of a mediator, as someone who would serve to bridge the gap between Left and Right while helping to heal the wounds the war had caused. ${ }^{2}$ As an examination of the Conference proceedings will show Eisner's performance at Berne appears calculated to fill the role for which he cast himself. It was truly a brilliant effort; it saved the Berne Conference. Yet this very success probably insured the ultimate failure of the attempt to reconstruct the International. What both Eisner and the majority of the Opposition failed to recognize was that it is sometimes necessary for something to die in order that it may live.

Originally scheduled for Paris, the site of the peace talks, the International Labor and Socialist Conference was forced to find another location when the French government let it be known that no Socialists from "enemy" countries would be allowed to enter France. ${ }^{3}$ It was then decided to hold the conference in Lausanne, only to have the Swiss authorities rule against either Lausanne or Geneva as a conference site. The conference organizers finally agreed upon Berne, but the Germans now requested and were granted a postponement until after their national elections had been completed. The actual opening session was

${ }^{1}$ Four Independent Social Democrats, including Party chairman Haase, attended and actively participated in the Third Zimmerwald Conference held in Stockholm during early September 1917, see "The Independent Social Democratic Party and the Internationals", pp. 59-64. Moreover, during its first year of existence the USPD gave 1,500 marks to "Angelica", i.e., to the Secretary of the Zimmerwald Movement Angelica Balabanova, see the USPD Kassenbericht for the period April 1, 1917 to March 31, 1918, in the Zentralparteiarchiv of the Institut für Marxismus-Leninismus, Berlin, 8/13 Reichskanzelei Unabhängige Sozialdemokratische Partei, I, 25. Georg Ledebour, who was in prison at the time his party decided to attend the Berne Conference, later claimed that the USPD had violated an agreement reached at the Third Zimmerwald Conference by going to Berne without first consulting the other Zimmerwald parties, see USPD, Protokoll über die Verhandlungen des ausserordentlichen Parteitages vom 30. November bis 6. Dezember 1919 in Leipzig (Berlin, n.d.), p. 356. For Eisner's contact with the Opposition at Berne, see Annie Kriegel, Aux origines du communisme français, 1914-1920 (Paris, 1964), I, p. 252.

2 See the detailed account of Eisner's speech in the Deutsches Theater, Munich, on February 13, in Extranummer.

${ }^{3}$ For background on the events leading up to the Conference, see the letter of Hjalmar Branting to the Swiss dated January 3, 1919, in the SPS Archiv, Berne; Mayer, Politics and Diplomacy, pp. 378ff.; Braunthal, History of the International, II, pp. 150-151; and Fainsod, International Socialism, pp. 249-250. 
then postponed until February 3 in order to insure the presence of Arthur Henderson, one of the conference's prime movers, who had suddenly been called to Paris to meet with the British government's delegation to the peace conference. Yet despite Henderson's absence, closed preliminary sessions were held during the week of January 26 with those delegates who had already arrived.

Hjalmar Branting and Camille Huysmans directed these preliminary sessions. Their purpose was to iron out differences between the various delegations and to arrive at a general order of business away from the glare of publicity. Nevertheless this effort to prevent a major public display of disunity went for naught as evidenced by the first plenary session of the Conference on February 2. ${ }^{1}$ The direct confrontation the International's leaders had been attempting to avoid was brought on by Albert Thomas, a right-wing French Socialist and former wartime munitions minister who had arrived just in time for the opening session. Addressing the Conference immediately after the introductory formalities had been completed, Thomas lambasted both the German Majority (SPD) and the Bolsheviks, and demanded a change in the agenda, proposing as the first order of business a thorough discussion of

1 The only "official" published record of the Conference proceedings is to be found in the Official Bulletin of the International Labour and Socialist Conference which the press committee of the Conference published between February 3 and 21 in English (8 issues), French (11 issues) and German (12 issues). These were, however, only summary accounts of the proceedings. The last Bulletin to appear in English carried a notice that a "complete Journal of the Proceedings of the Berne Conference is now being prepared in the English, French and German languages. It will contain all the verbatim speeches, resolutions and memorandas, etc. as preserved in the official stenograms of the Conference." But for some reason - probably financial - such a "Journal" was never published. However, "L.S.I. Berne Congress [sic] February 1919", British Labour Party Archives (hereafter referred to as BLP Berne protocol), contains a large collection of material which appears to have been originally intended for such a project. A similar collection is to be found in the archive of the Bureau of the Second International (BSI) in Antwerp. While it is unclear whether these protocols are a stenographic or an edited record of the proceedings, they are by far the best account of the delegates' speeches that I have found. However, since representatives of the press were present at all plenary sessions, it is sometimes helpful to compare the above record with the accounts given in the Socialist papers. The latter are also the best published source for a record of the preliminary meetings held from January 26 to February 2 . The only published, and apparently the only extant, accounts of the commission meetings which took place during the Conference are in Pierre Renaudel, L'Internationale à Berne (Paris, 1919), and Antonio de Tomaso, La Internacional y la Revolucion (Buenos Aires, 1919). John de Kay, the Conference's millionaire patron, published a summary of the public sessions in The Spirit of the International at Berne (Lucerne, 1919), which is of little value. 
the "war responsibility question" and as the second, a discussion of "democracy and the realization of Socialism" - a poorly camouflaged device for condemning the Soviet Union. Following Thomas's broadside, the Conference at once adjourned for dinner, an adjournment that may well have saved it from immediate dissolution. That evening Paul Mistral, a member of the more radical French Majority, addressed the delegates. He agreed that a discussion of "war responsibility" was necessary, but declared it even more important that the Conference examine ways and means of influencing the content of the Peace and the situation created by the Revolutions in eastern and central Europe. In keeping with this Opposition oriented approach, Mistral proposed that, as its first order of business, the Conference salute the Russian and German revolutions. The evening's debate then concluded in a less than harmonious fashion with Wels from the German Majority replying to Thomas, and Renaudel from the French Minority attaking Wels. ${ }^{1}$

This set the stage for Kurt Eisner's first performance as Conference mediator. Opening the discussion on the following morning, the Bavarian Minister President emphasized the need for "truth and clarity", as the basis for the new International, and Socialist unity at both the national and international levels. ${ }^{2} \mathrm{He}$ explained away the twelve million votes the SPD had just received in the German national elections compared with his own party's relatively poor showing, as a result of the masses' desire for unity, and rejected the idea that the German Revolution was a fraud. Eisner then went into a lengthy discussion of war responsibility, declaring that at the outbreak of the war the situation was, due to the threat of Russian attack, unclear. Indicating that he too had been among those Germans who had failed to see through the government's deception, Eisner - in a typical gesture - called on Wels and the SPD to recognize the fact that they had been deceived for the past four and a half years. Rejecting as a "Bolshevik" argument Wels's assertion that world capitalism was responsible for the war, he declared:

"Today it is certain that this war was initiated, without any political foresight or military insight by a small band of completely mad German militarists, who were allied with heavy industry and with imperialists, capitalists and princes. The puzzle of the world

1 BLP Berne protocol, February 3, 1919; Berner Tagwacht, No 28, February 4, 1919.

2 For Eisner's speech see BLP, Berne protocol, February 4, 1919; Freiheit, No 64, February 5, 1919. It was also published as a pamphlet by Bund Neues Vaterland. See Kurt Eisner, Schuld und Sühne (Berlin, 1919). 
war solves itself when one understands the souls and minds of the leading German militarists."1

According to Eisner, the international duty of the German Social Democrats once the war broke out should have been to overthrow the "guilty system", i.e., the imperial German government. Noting that the German Revolution did not come too early but rather four and a half years too late, he appealed to the SPD to recognize its mistakes, reject the old system and help rebuild the International. To the foreign Socialists he declared that while Germany was guilty, it was not the German people but rather the German military and the old regime that were guilty. Citing examples of the German people's opposition to the war, particularly the mass strikes of January 1918, he defended the revolutionary character of the changes that had occurred in Germany. Without question Eisner's lengthy address was one of the most well received speeches given at the Conference (although the same could not be said of its reception in Germany). Conceivably this was related to the fact that his remarks had something to please nearly everyone present.

Eisner found the perfect second in Karl Kautsky, who was enthusiastically greeted by the Conference participants when he took the podium to open the afternoon session. ${ }^{2}$ The old Socialist theorist covered essentially the same points Eisner had dealt with and reiterated much of what his colleague had stated earlier. Yet the very fact that Kautsky took a somewhat harder line vis-a-vis both the German Majority and on the Peace issue must have made Eisner's remarks seem that much more reasonable to many delegates, thereby increasing Eisner's status as a potential mediator. Paradoxically Eisner's revolutionary image was also enhanced through Kautsky's remarks. Whereas Eisner had spoken of mass action and revolution to stop the war, Kautsky advocated nothing stronger than parliamentary action even though he admitted that the greatest threat to the International had been the possible victory of German militarism.

Actually what is striking in both the speeches of Eisner and Kautsky is their admission of a singular German war guilt, at least the old

1 My translation is from the German text found in both the BLP and BSI archives. It differs somewhat from that of Mayer (Politics and Diplomacy, p. 391), who apparently relied on Renaudel's (L'Internationale, p. 46) account of Eisner's speech.

2 BLP Berne protocol, February 4, 1919, lists "lively applause" as does the BSI copy. Actually the latter appears to be the more complete copy of Kautsky's remarks. It includes, for example, a reference to Rosa Luxemburg and. Karl Liebknecht in which Kautsky memorialized them as "martyrs in the proletariat's struggle for liberation". This statement along with the fact the delegates responded to it by rising from their seats is not included in the BLP version. 
system's guilt. Here they may have been influenced by their unique opportunity to have examined the archival records of the Imperial and State governments. Probably no one at the Conference even approached their familiarity with the secret documents concerning the outbreak of the war. At the same time their failure to criticize the Entente counterparts of the SPD as well as their willingness to censor the absent Bolsheviks appears somewhat opportunistic. In fact the speeches of both men seem designed more to win over and conciliate the rightwing of the Entente Socialists than to get at the "truth and clarity" Eisner believed necessary for the rebuilding of the International. Neither appeared to have any doubt that the International could be reconstructed if only the SPD would recognize its mistakes! In fact Kautsky and Eisner presented a rather singular position when compared with the other delegations. While the official USPD contingent would have to be considered "internationalist", this "internationalism" was severely limited by the delegation's decided anti-Bolshevism. Certainly Kautsky and Eisner were not "internationalist" in the sense of the French Majority Socialists who were quite willing to condemn all the "nationalists" present at the conference, nor in the manner of Friedrich Adler who was rather skeptical of the "international" nature of the Conference, or even of Pieter Troelstra who did not hesitate to condemn Thomas's anti-Bolshevism. ${ }^{1}$ However, the value of the conciliatory position taken by Eisner and Kautsky on this and other issues was of tremendous importance to the actual functioning of the Conference. It is quite likely that without their moderating influence the gathering would have degenerated into a shouting match between French and German nationalists, and in turn would have led to the actual breakup of the Conference. Equally if not more important in this regard was Eisner's behind the scenes role. Following the conclusion of the plenary session on February 4, the "responsibility" question was given over to a ten-man commission under the chairmanship of Branting. Eisner was primarily responsible for the successful conclusion of this commission's work. His draft served as the basis for the final resolution which the commission, after a night and a day of deliberations, unanimously presented to the full Conference, where it was accepted with only one dissenting vote. ${ }^{2}$

The essence of Eisner's proposal was a simple compromise. It consisted of two parts, a preliminary declaration by the German Majority Socialists, followed by a resolution of the whole Conference. The SPD's statement admitted the Imperial German government's responsibility

1 See BLP Berne protocol, February 5, 1919

2 Renaudel, L'Internationale, p. 52. 
for the war but celebrated the fact that the German Revolution "had overthrown and destroyed the old system". The Conference then went on record "affirming the revolutionary spirit of New Germany and its complete separation from the old system which was responsible for the war". Clearly Eisner was pragmatically attempting to bridge the chasm that separated the German Majority and the French Minority on this question. ${ }^{1}$ He seems to have had little trouble with the French, yet despite the conciliatory nature of his proposal the German Majority proved difficult. Apparently it took a good deal of pressure from other non-allied delegates before the SPD grudgingly agreed to an amended version of the Eisner resolution.

It is not completely clear how important these amendments to Eisner's original proposal were in securing the committee's endorsement and the Conference's acceptance. Mayer asserted that the "reference to the "declaration made by the German delegates during the [concurrent] debate on the League of Nations"' helped the SPD agree to the final version. This seems questionable, because this addition changed nothing essential in the initial proposal. ${ }^{2}$ Eisner's original concept was modified by the addition of a final sentence indicating that the "worldhistoric question of the responsibility for the war" would be left to a "future International Congress". ${ }^{3}$ Whereas Eisner's proposal acknowledged that the "question of responsibility for the war had been made clear", the amendment read "question of immediate responsibility"." These two changes were most important, for while Eisner's compromise could have conceivably resolved the "war guilt" question once and for all (at least formally), the final version intentionally left the matter open. How important this was in securing Conference approval is another matter. The SPD had objected to the first part of Eisner's original proposal but under pressure accepted it unchanged; they had objected to the amended second part and even walked out of the

${ }^{1}$ For the SPD and French Minority resolutions see ibid., pp. 50-52. In his February 13 speech in Munich, Eisner emphasized his "bridge-building" function, see Extranummer.

2 Politics and Diplomacy, p. 393. Mayer refers to this amendment as "Henderson's proposal". Formally this is correct but the section he quotes was suggested by the Austrian Ellenbogen. See Renaudel, L'Internationale, p. 55.

3 For the final version of this resolution see International Labour and Peace (London, 1919), p. 3. For Eisner's proposal see Renaudel, L'Internationale, pp. 53-54. The Eisner Nachlass now located in the Zentralparteiarchiv of the Institut für Marxismus-Leninismus contains the German original.

4 Mayer, Politics and Diplomacy, p. 393, asserts that this particular change was proposed by Branting. However Renaudel, L'Internationale, p. 55, would seem to claim credit for the addition of "immediate". The idea for the concluding sentence was clearly Branting's. (Emphasis added.) 
committee sessions, yet again under pressure, they eventually agreed to this as well. ${ }^{1}$ Based on the initial remarks of Wels and Müller before the Conference on February 3 and 4 , it is possible that the consideration of the "world-historic question of responsibility" at a future meeting of the International may have had a certain appeal for the SPD. ${ }^{2}$ Yet their continued opposition to the revised proposal belies this. Probably more important was the fact that the Belgian Socialists were intentionally absent and were liable to continue to refuse to participate in the International if Eisner's original disposition of the "question of responsibility" had been accepted unchanged. Whereas Eisner himself took great pride in his role in realizing a compromise and maintaining the immediate unity of the International, this amendment seems to have been aimed at the future unity of this body. ${ }^{3}$

While the commission on "war responsibility" was working into the early morning hours the Conference had gone ahead with its other business. Debate on the question of the League of Nations, originally listed as the first item on the agenda, proceeded smoothly. Eisner spoke briefly on this subject and expressed a point of view which was in accord with the majority of the Conference but was certainly at variance with some of his comrades in the USPD. ${ }^{4}$ Praising the idea of a "proletarian League of Nations" as the means of realizing true peace, he rejected as "faint-hearted" the arguments of those who contended that no real League of Nations was possible so long as capitalist society existed. Eisner suggested that the League impose economic sanctions to enforce its decisions and that the principles of the League be incorporated in national constitutions. Once again his remarks were warmly received by the Conference. At the conclusion of the February 6 morning session the original commission proposal on the League was unanimously accepted by the delegates with two minor additions.

That afternoon public discussion of the territorial question began. While this debate continued for over two days often in a heated manner, a matter fraught with graver potential was being resolved off the Conference floor. This issue was whether or not the delegates should consider a public examination of the question of "democracy and dictatorship", i.e. Bolshevism. Probably aware that this issue could seriously divide the Conference and might even result in its breakup,

1 Renaudel's account suggests that the crucial pressure came from Branting and Ellenbogen.

2 BLP Berne protocol, February 3 and 4.

3 See Extranummer.

- BLP Berne protocol, February 6. 
Camille Huysmans tried to have the matter postponed until after its formal conclusion, arguing the shortness of time and the press of the other business. ${ }^{1}$ This ploy apparently failed when the Germans - at whose request it had initially been decided to conclude the deliberations on February 8 - agreed to stay through February 9.2 Whatever the motivation for the German decision it resulted in the Bureau accepting a proposal by Branting that a commission be formed to examine the question of "democracy and dictatorship" and report back to the full Conference. ${ }^{3}$

This decision brought the Opposition back to life. That evening they met privately to discuss their tactics on this question. In contrast to their earlier gathering the Opposition caucus on February 6 proved somewhat more productive. ${ }^{4}$ It seems to have been decided at this time to use every possible maneuver, including the threat of a walkout, delaying tactics and motions for adjournment, in an attempt to prevent the question of "democracy and dictatorship" from coming to the Conference floor. In the event this occurred anyway the Opposition was now prepared, if necessary, to offer its own resolution to prevent the Conference as a whole from going on record against the Bolsheviks.

Having finally decided to act, the Zimmerwaldian Opposition was also about to become visible. On the following evening at a public rally for the International hosted by Robert Grimm, the Opposition addressed the Berne workers. ${ }^{5}$ Friedrich Adler was the featured speaker on a

1 See Berner Tagwacht, No 31, February 7, 1919, Beilage.

2 Vorwärts, No 70, February 7, 1919.

${ }^{3}$ Berner Tagwacht, No 32, February 8, 1919; Vorwärts, No 71, February 8, 1919; L'Humanité, No 5410, February 8, 1919. The Conference Bureau was composed of Branting (Sweden), president; Wibaut (Holland), and Dr Justo (Argentina), vice presidents; and Henderson (England) and Seitz (Austria). Dr Ellenbogen (Austria) replaced Seitz when the latter left the Conference on February 3. All can be considered anti-Bolshevik and right-wing in their orientation.

4 The Arbeiter-Zeitung (Vienna), No 35, February 5, 1919, contains a notice of this meeting but there is no published record of what took place at it. The brief account I have given is based on what the Opposition did during the Conference with regard to the "democracy and dictatorship" question following this meeting. For example, Renaudel, L'Internationale, p. 125, reports that in the commission Adler threatened a walkout of thirty-three delegates if the matter came to the floor. During the February 8 debate on territorial questions Renaudel publicly accused Adler of stalling in an attempt to keep the issue of "democracy and dictatorship" from the Conference, see L'Humanité, No 5412, February 10, 1919. Both in the commission and the subcommittee the Opposition made unsuccessful motions for adjournment. Finally nearly all the Opposition signed the AdlerLonguet resolution on "democracy and dictatorship".

5 Berner Tagwacht, No 33, February 10, 1919, Beilage. The rally was well publicized. Front-page advertisements for it appeared in the Tagwacht on February 6 and 7. 
roster that read like a "who's who" of the left-wing present at the Conference: Faure and Loriot from the French Socialist Party majority, Scheflo from the Norwegian Labor Party, Burian from the Czech minority, Morgari ${ }^{1}$ from the Italian Socialist Party and Herzfeld from the USPD. Speaking before a packed house Adler told the Swiss that those foreign Socialists present that evening understood the SPS decision to boycott the Conference. Still he defended those who did attend, arguing that while the International Conference was inadequate, it did offer an opportunity for contact with foreign Socialists. After reviewing the history of the International since 1914 and noting its failure to have any influence on the war, Adler concluded with what was essentially an expression of the main Opposition position.

"Apply the principles of the international movement to the situation existing in each country. We will only go forward on the basis of the class struggle. The International patched together in Berne is a bourgeois International with all its defects. It cannot fulfil its primary function which is to organize the proletariat as a class for the struggle. The signals are already aglow, a final struggle must take place. The proletarian International of the class struggle will free us all."2

To advance these ideas before a sympathetic audience was one thing, to try and propagate them at the Conference quite another. Still Adler had not given up trying; a short time later he was to be found doing battle before the opening session of the commission on "democracy and dictatorship". No other problem considered at the Conference evoked the emotional response and generated the general interest that "democracy and dictatorship" did. The commission itself was twice as large as any of its predecessors ${ }^{3}$ and packed with outspoken antiBolsheviks including Kurt Eisner. Typically, however, Eisner did not permit his ideological predilections to prevent his working for inter-

\footnotetext{
1 Morgari and Giulio Casalini had been sent to Berne by the Italian Socialist Party to participate in the Berne Conference under certain conditions. Because of the "social patriotic" orientation of the Conference the two Italians withdrew as delegates but continued to attend the plenary sessions in their capacity as journalists. See Morgari's statement in Berner Tagwacht, No 36, February 13, 1919, Beilage.

2 Berner Tagwacht, No 33, February 10, 1919, Beilage.

${ }^{3}$ Among the members of this commission were the following: Justo and de Tomaso (Argentina); Adler (Austria); Grumbach, Longuet and Renaudel (France); Eisner, Kautsky and Wels (Germany); Henderson and MacDonald (Great Britain); Troelstra (Holland); Kunfi (Hungary); Axelrod, Bienstock, Gavronsky, Roussanov, Roubanovitch, Sukhomlin (Russia); Goussorsky (Bund); Vuolyoki (Finland); Branting (Sweden).
} 
national unity. Once again he took on the role of the "honest broker" in the hope of realizing harmony and solidarity.

Initially Eisner, like the Opposition, attempted to side-step the issue by calling for adjournment. ${ }^{1}$ Only after this maneuver failed did he place a resolution before the commission. ${ }^{2}$ Once more his overriding concern with unity was clearly evident. Nearly half of Eisner's proposal was devoted to this theme, specifically the need for maintaining unity in order to realize Socialism. The remainder pertained to Bolshevism. Eisner proposed sending a study commission to Russia and urged that the subject of Bolshevism be placed on the agenda of the next International Congress. Throughout the proposal he scrupulously avoided anything that might be construed as an attack on, or an endorsement of, Bolshevism. By contrast three of the other four resolutions submitted to the commission - those of Branting, Renaudel and Wels - were hostile to Soviet Russia although only Wels criticized the Bolsheviks by name. The one other proposal, that of Ramsay MacDonald, welcomed the Russian as well as the Austrian and German revolutions, condemned military intervention in Russia, and, like Eisner's, urged that a study commission go to Russia and report back to the next International Congress. ${ }^{3}$

Despite over five hours of debate none of these resolutions proved acceptable to a majority of commission members. In an attempt to break this impasse, a subcommittee was formed to work out a compromise. In this body the anti-Bolshevik bias of the commission as a whole was reduced somewhat. Besides the authors of the five proposals, the subcommittee included two members of the Opposition, Adler and Longuet, and two Russian émigrés, Axelrod and Sukhomlin. ${ }^{4}$ Nevertheless the Opposition's efforts to avoid the issue were no more suc-

1 Renaudel, L'Internationale, p. 129; Tomaso, La Internacional, pp. 194-195. 2 Renaudel, L'Internationale, pp. 129-130 (in French); Arbeiter-Zeitung (Vienna), No 52, February 22, 1919, and Freiheit, No 103, February 26, 1919 (in German). For a copy of this resolution see Appendix I.

${ }^{3}$ Le Populaire, No 301, February 10, 1919. A copy of the Renaudel proposal as well as the MacDonald proposal is to be found in French in Renaudel, L'Internationale, pp. 127-128. The Wels resolution is also to be found in this work on pp. 130-131. However, in the latter case $I$ have used an original copy of the resolution in German located in the Branting Collection, Arbetarrörelsens Arkiv, Stockholm. I have not been able to locate a copy of Branting's proposal.

4 Renaudel, L'Internationale, p. 131, n. 1, lists a tenth member of this subcommittee, the Russian Bienstock. However two pages later he lists only nine subcommittee members and Bienstock is not among them. The Arbeiter-Zeitung (Vienna), No 41, February 11, 1919, refers to a "nine member subcommittee", as does Branting in his remarks on February 9. See Berner Tagwacht, No 34, February $11,1919$. 
cessful here than in the full commission. A motion to adjourn failed and a resolution submitted by Longuet fared no better. ${ }^{1}$ This proposal took the standard Opposition line that given the absence of so many delegations no judgement should be made on the Soviet system and it urged the Conference to avoid either a condemnation of "dictatorship" in the name of "democracy" or "democracy" in the name of "dictatorship". Like the MacDonald resolution it included the study commission idea and a denunciation of the intervention in Russia. Not surprisingly therefore, the Opposition appears to have thrown its support behind MacDonald's proposal after Longuet's was withdrawn but this measure also failed to rally sufficient backing. Yet if the Opposition was too weak to force the acceptance of its position, it was still strong enough to block the adoption of any resolution it considered unacceptable. The result was a deadlock that set the stage for Kurt Eisner's next major effort at consensus building. In a clear attempt at reconciling the various points of view expressed in the commission and subcommittee, he submitted a second proposal. ${ }^{2}$

Considerably longer and more specific than his initial recommendation Eisner's new resolution was really an amalgam of ideas contained in previous proposals. ${ }^{3}$ Although he did not abandon his original call for unity and a study commission, the emphasis in Eisner's proposed compromise was on a fundamental relationship between "democracy" and "socialism". The former was seen as a necessary precondition for the latter while the political dictatorship of a minority was only recognized as legitimate in a revolutionary situation and on a temporary basis. Despite the revisionist theoretical orientation of this proposal it was not to be accepted as it stood, ironically enough because the majority apparently found it a bit too radical. Instead the subcommittee decided, over the objection of the Opposition, to instruct chairman Branting to formulate a resolution based on the resolutions already submitted. ${ }^{4}$

The final product of Branting's labor, however, bears a remarkable similarity to the compromise put forth by Eisner and with good reason.

1 L'Humanité, No5410, February 8, 1919, referred to this as "une Motion FrossardFaure-Verfeuil-Longuet". However the British Socialist journal The Call, No 152, March 6, 1919, published an English translation of the resolution "proposed by Loriot, Verfeuil, Frossard and Paul Faure". Renaudel, L'Internationale, p. 131, says that it was put to the subcommittee by Longuet but later published under the names of Frossard, Verfeuil and Loriot.

2 Arbeiter-Zeitung (Vienna), No 52, February 22, 1919, and Freiheit, No 103, February 26, 1919.

3 For a copy of this resolution and the sources from which it was derived see Appendix II.

4 Renaudel, L'Internationale, p. 133. 
Eisner evidently collaborated in editing the Branting text. ${ }^{1}$ Moreover a comparison of the commission or "Branting" resolution on "democracy and dictatorship" with Eisner's second proposal strongly suggests that the latter was used as the basis for the former. ${ }^{2}$ Yet if Karl Kautsky was correct in referring to the final resolution as largely Eisner's work, he was guilty of an overstatement in calling it "Eisner's resolution". ${ }^{3}$ Not only was the commission version a good deal longer than Eisner's compromise attempt but, more importantly, it was also somewhat more conservative. This ideological coloring is observable in certain passages traceable to Branting or Renaudel and especially in the elimination of Eisner's reference to dictatorship. Even the temporary exercise of a revolutionary dictatorship was obviously anathema to the Conference's right-wing leadership. Still an emphasis on democracy as part and parcel of socialism was common to both the final draft and Eisner's proposal, as was a basic distinction between political and economic change. While the political transformation of society might sometimes be realized by popular uprising (revolution), any economic alteration had to be the result of a methodically planned process built upon a democratic foundation. Significantly neither resolution made any mention of the blockade of, or the intervention in, Soviet Russia.

Over the protests of Adler and Longuet, the "Branting" resolution was approved by a majority in the commission and reported to the plenary session of the Conference late in the evening of February 9. The day's deliberations had been harmonious up to this point. With hardly any debate the Labor Charter had been approved unanimously; after only a short debate the Eisner-Renaudel resolution on prisonersof-war was accepted in slightly modified form, $\mathbf{4}$ and finally, in contrast to the often bitter debate of previous days, a general statement on territorial questions was readily adopted. The outward unity of the Conference was not even upset when a telegram from Theodor Liebknecht was read protesting the SPD's admission to the Conference and accusing it of covering up the murder of his brother Karl. ${ }^{5}$ The open ex-

1 Tomaso, La Internacional, p. 117. Through Renaudel, Tomaso also submitted a proposal to the subcommittee, see p. 197.

2 See Appendix III.

3 USPD, Protokoll-Berlin, p. 123.

4 For a copy of the original proposal see Berner Tagwacht, No 34, February 11, 1919, or Troelstra Collection, 451/12, Internationaal Instituut voor Sociale Geschiedenis, Amsterdam; for the resolution as adopted see International Labour and Peace, p. 11, or Official Bulletin of the International Labour and Socialist Conference, No 8, February 21, 1919.

${ }^{5}$ As noted above the Conference had earlier stood silently in honor of Liebknecht and Luxemburg but this was as far as it was prepared to go. For the text of 
change that followed Branting's report from the commission on "democracy and dictatorship" shattered this façade. After only one person had spoken on the commission resolution a procedural debate began over the question of the speakers' list, the authenticity of the resolution presented, the manner in which the vote should be conducted and whether or not the resolution should be voted on at all. This quickly degenerated into a verbal donnybrook and Huysmans averted complete chaos and the premature end of the Conference only by calling for a recess. The proceedings were adjourned at 1:15 a.m. and the concluding session was scheduled for later that morning with twenty-four delegates already registered to speak. ${ }^{1}$

The level of division and acrimony was unprecedented and in marked contrast not only to the previous day's proceedings but also to the reception the report of the commission on war responsibility had received earlier. Clearly the other major stumbling block before the Conference, the matter of "war guilt", had been neatly resolved off the Conference floor and the commission resolution adopted with little debate. Yet now the Conference appeared in danger of breaking up. If the efforts of the commission on the "question of responsibility" had been crowned with success, its counterpart on "dictatorship and democracy" succeeded only in exacerbating the problem it was formed to resolve. In both cases a compromise proposal of Eisner's provided the basis for the final commission resolution, but while one was endorsed almost unanimously the other was to be the object of a fierce debate. Why?

Part of the difficulty (but by no means all of it) was related to Eisner himself. On the question of war responsibility his personal convictions combined with an often overlooked pragmatism to produce a near perfect compromise; in the case of "democracy and dictatorship" his genuine antipathy for Bolshevism militated against a similar tour de

Liebknecht's telegram, see Freiheit, No 62, February 4, 1919, or Leipziger Volkszeitung, No 29, February 5, 1919. Theodor Liebknecht had hoped to address the Conference personally but he failed to receive the necessary papers in time to travel to Berne. As was to be expected there were a number of explanations as to why Liebknecht did not receive his passport in time to attend the Conference. The USPD claimed government chicanery, while the SPD declared Liebknecht had simply applied too late. Under the circumstances it is quite possible that the latter explanation was at least formally accurate. However considering the German Foreign Office's efforts to keep Eisner home, it seems rather likely that they were in no great hurry to assist another "undesirable" in his efforts to attend the Conference. For the controversy over Liebknecht's inability to attend the Conference, see Freiheit and Vorwärts for early February 1919.

1 Berner Tagwacht, No 34, February 11, 1919, and Arbeiter-Zeitung (Vienna), No 41, February 11, 1919. 
force. Nevertheless he again came quite close and it does not seem unreasonable to suppose that unity might once again have been attained had the more conservative elements in the commission agreed to his second proposal in its original form. This assumes that the Opposition had not already decided to place an alternative resolution before the full Conference regardless of what the commission proposed. Based on the participation of Adler and Longuet in the subcommittee, as well as the text of the resolution they eventually submitted to the delegates," this is most unlikely. The "Adler-Longuet" resolution simply demonstrated that, for all its diversity and the concern of its more moderate elements with unity, the Opposition found the commission resolution an inadequate compromise and consequently unacceptable. In fact it appears that it was essentially the adamant anti-Bolshevist stance of the Right within the commission, rather than any action on the part of the Left, that frustrated Eisner's second compromise attempt and spurred the Opposition on to independent action.

If anything approaching unanimity was now impossible it was obvious, given the Opposition's distinctly minority position at Berne, that the "Branting" resolution could easily secure a majority of the delegates still present. Nevertheless when the debate reopened on February 10, the Conference accepted Adler's motion eliminating a formal vote on the question probably in the interest of unity and perhaps under the threat of a minority walkout. Instead, the various delegations and delegates were simply to state their positions. ${ }^{2}$ The first such statement indicated the extent to which the International was still divided. Fernand Loriot, an outspoken member of the Opposition, condemned the Berne Conference completely. ${ }^{3}$ His wrath was particularly directed against the right wing and its domination of the proceedings, but he also had harsh words for those on the left who had cooperated with these Wilsonian "pseudo-socialists". Declaring solidarity with the Russian Communist Republic, Loriot concluded by expressing his hopes for the victory of the "revolutionary proletariat" in Germany and the world. His was the extreme opinion within the Conference minority.

1 See below and Appendix IV, especially the final paragraph.

2 Berner Tagwacht, No 34, February 11, 1919.

3 Ibid., No 33, February 10, 1919. Loriot had attempted to present this statement at the start of the evening session on February 9, but was ruled out of order as the Conference was at that time debating the prisoner of war question. However he apparently released the statement to the press at this time anyway. Another French delegate, Pressemane, also presented a personal resolution at the final session. For the text see Renaudel, L'Internationale, pp. 138-139. 
More representative of the Opposition mainstream was the resolution on "democracy and dictatorship" presented by Adler as an alternative to the "Branting" proposal. ${ }^{1}$ Significantly Loriot was not among the 14 delegates who signed this statement, probably because it was simply too moderate for his tastes. ${ }^{2}$ While Loriot seems to have considered Berne as a chance for confronting the "social-patriots" and right-wing elements within the International, the majority of the Opposition were more concerned with the reconstruction of a unified, effective International or what the Adler-Longuet resolution referred to as the "reconstitution of the international front of the conscious revolutionary proletariat". To this end they had come to Berne, albeit reluctantly and aware of the many who were staying away. But the Conference decisions had proved too little, too late and now faced with a resolution on "democracy and dictatorship" that would "inevitably increase the difficulties of the International" they were forced to protest. The Adler-Longuet declaration objected to the idea of applying "any kind of stigma [...] to the Russian Soviet Republic", emphasizing the lack of reliable information available and the International's "old principle of hearing both sides". The Opposition was most concerned that the Conference "would make the meeting of the working classes of all countries more difficult in the future" by such a "premature judgement on political methods". Consequently the signatories to the Adler-Longuet resolution stated that they would not be bound by the Majority resolution because "we do not wish to be parties to any action against the International". Notable by its absence from this Minority statement was any expression of solidarity or support for the Soviet Republic, in marked contrast not only to Loriot's declaration but also to the proposal Longuet had earlier submitted to the subcommittee. $^{3}$ Probably this was the result of an attempt to construct an alternative to the Commission's resolution that would appeal to as many Conference participants as possible, a decision indicating a victory of the moderate elements within the Opposition. Nevertheless it is questionable whether a more radical formulation of the Opposition's position would have had any less appeal to the Conference than did the Adler-Longuet resolution. An informal canvas shortly

1 Generally referred to as the Adler-Longuet resolution. See Appendix IV.

2 Kriegel, Aux origines du communisme français, p. 251, refers to Loriot as a "Left-Zimmerwaldian". Besides Adler and Longuet the Opposition resolution was signed by Cachin, Faure, Frossard, Mistral, Pressemane and Verfeuil (France); Scheflo and Tranmael (Norway); Johnson and O'Shannon (Ireland); Petridis (Greece); Herzfeld (Germany).

$s$ Even Pressemane's relatively moderate statement objected to "all foreign intervention, military or economic". 
before the Berne Conference concluded showed that the great majority of those present supported the "Branting" (or commission) resolution on "democracy and dictatorship", although Fritz Adler was quick to claim a majority of the absentee parties for the "minority". ${ }^{1}$ Adler's assertion was not necessarily an empty rhetorical gesture, if anything a majority of the parties not officially represented at Berne would probably have found that the "minority" resolution did not go far enough. Where the Opposition's real weakness lay was in waiting until literally the last minute before publicly challenging the Conference majority in the name of the entire International. Had they done so earlier, had they shown more concern with relating the International to the revolutionary situation Europe found itself in, Berne might well have taken a different course.

As it was, the International Labor and Socialist Conference, the first gathering of the International since the end of the war, was characterized as much by who did not attend as by who did attend, by what it did not do as much as by what it did do. Without question the one followed from the other. The absence of either the extreme Right - Belgians and the American trade unionists - or the extreme Left - Bolsheviks, Spartacists, Swedish and Danish Left Socialists - undoubtedly made possible a certain amount of reconciliation and compromise (which kept the Conference from breaking apart). At the same time the absence of the more moderate Left - Swiss, Italians, Serbians, Rumanians, Left Social Revolutionaries of Russia - as well as the composition of many of the delegations in attendance influenced considerably the manner and matter of the deliberations. Certainly it is at least strange that in a revolutionary epoch a discussion of the revolution was absent from the agenda. In fact the only real consideration of revolution sneaked in as a camouflaged attack on the Russian Bolsheviks. The question of Socialists in coalition governments, particularly during the war, was not something which would have been quite so easily settled had the Left been more heavily represented at the Conference. Possibly the attempts to influence the Paris Peace Conference would even have gone beyond resolutions and watchdog committees, beyond the attempt to influence and/or support Wilson, had not the Right dominated the Conference. On the other hand it was the very presence and cooperation of at least a section of the Left at Berne that gave the ultimately ineffectual actions of the Conference a certain legitimacy. This need not have been. It was not simply the result of the Opposition's minority status at Berne. Rather it was a product of their hesitancy to

1 Arbeiter-Zeitung (Vienna), No 42, February 12, 1919. 
act, their reluctance to confront the Conference with demands for change and relevant action. One cannot but wonder whether International Socialism would not have been better served at this point in time by a little less concern with formal unity and a little more with Eisner's call for "truth and clarity". After all, the immediate consequence of the Opposition's failure to influence significantly the reconstruction of the old International was the formation of a new body, the sectarian Communist International.

If Berne was something of a "rump-conference" it was certainly more representative of International Labor than the meeting that took place in Moscow a month later. It is even questionable whether the founding Congress of the Communist, or Third, International was as representative of the Left as the Opposition caucuses during the Berne Conference. Nevertheless the forming of the Comintern effectively cut the ground out from under the Opposition. More importantly it undermined the tentative attempts undertaken by the Swiss, the Scandinavian and German Left following the Berne Conference to reconstruct the International along Zimmerwaldian lines. ${ }^{1}$ Although important elements within the Opposition continued to work for the implementation of similar ideas for another four years their position between the extremes

1 On the day after the Berne Conference concluded the Swiss Leadership met to evaluate the results of its discussions with the Opposition. Robert Grimm was then appointed to draft a circular letter to all the parties and groups affiliated with the Zimmerwald movement for the purpose of calling a conference prior to the scheduled fall Congress of the Second International (SPS Archiv, Geschäftsleitung Protokoll, February 11, 1919, and SPS, Geschäftsbericht, op. cit., p. 49). A few days later Party Secretary Fritz Platten left for Russia (Berner Tagwacht, No 37, February 14, 1919; James W. Hulse's assertion in The Forming of the Communist International (Stanford, 1964), p. 18, that Platten had not returned to Switzerland since the spring of 1917 is incorrect). Although the reasons behind Platten's trip are not completely clear it is likely they involved trying to secure Bolshevik participation in the proposed conference of Zimmerwald parties. (The possibility that Platten was responding to the January 24 broadcast from Russia inviting the "left Social Democrats of Switzerland" and others to the founding Congress of the Communist International seems unlikely. I have found no indication that this invitation was known to anyone in Western Europe until weeks after Platten had already left.) On February 18, after its delegates had returned from Berne, the Central Committee of the Norwegian Labor Party wrote at length to the Zimmerwald Commission in Stockholm urging it to coordinate action among the various $Z$ immerwald groups concerning the upcoming Congress of the Second International (Strom Collection, Göteborg University Library). At its National Congress in March the USPD adopted a program which included a demand for the "restoration of the Workers' International on the basis of a revolutionary Socialist policy in the spirit of Zimmerwald and Kienthal" (USPD, Protokoll-Berlin, p. 199). On May 8, an expanded national conference of this same party instructed its leadership to contact other revolutionary parties in order to build an International dedicated to the ideals of Zimmerwald and 
of Bolshevism and Reformism eventually proved untenable. ${ }^{1}$ The ultimate result was two "Internationals", one which evolved into little more than an adjunct of Soviet foreign policy while the other proved to be little more than a kind of Socialist League of Nations.

Despite the yeoman work Kurt Eisner performed at Berne it is doubtful if he could have in any significant way influenced these developments had he not been assassinated less than two weeks after the Conference concluded. As noted earlier many in Eisner's party, the USPD, were sceptical about the value of going to Berne and certainly the decisions taken at the Conference only reenforced these initial doubts. Had Eisner lived it might only have been to see his own party repudiate his role at Berne. Certainly an examination of the editorial comment on the Conference within the USPD press as well as the attitudes expressed by delegates to its national Congress a few weeks

Kienthal ("The Independent Social Democratic Party and the Internationals", p. 289). Finally on March 27, 1919, the Berner Tagwacht (No 72) carried a full page proclamation from the International Socialist Commission (ISC) in Stockholm which blamed the harassment of national governments for having prevented a new conference of the "Zimmerwald International". However it went on to claim that the Zimmerwald parties were nevertheless an International, "an International of Action".

In this context it should be emphasized that while it is clear that the Berne Conference was the catalyst that sparked the calling of the Moscow Congress (see for example Ruth Stoljarowa, "Zur Entstehungsgeschichte des Aufrufs zum 1. Kongress der Kommunistischen Internationale vom Januar 1919", in: Zeitschrift für Geschichtswissenschaft, XI (1968), pp. 1381-1401) the Bolsheviks were certainly aware of the existence of the Berne Opposition and the attempts to reform the International along Zimmerwaldian lines. Fritz Platten, as noted earlier, reported to the Congress on the former (see p. 175, note 4) and Otto Grimlund and Angelica Balabanova were present from the Zimmerwald Executive (ISC). In fact it is not unlikely that the Bolsheviks, who had been considering a break with the Zimmerwald movement since the fall of 1917 , intentionally undercut the attempts to reform the International in a Zimmerwaldian direction. Certainly the Moscow Congress's unilateral dissolution of the ISC strongly suggests this.

1 During 1919 and 1920 the most important attempts to realize these ideas were undertaken by the USPD. At one time or another the Germans received the cooperation of the French, Swiss, Austrian and Norwegian parties, as well as the Swedish and Danish Left-Socialists, the Independent Labour Party and the American Socialists. But their efforts were eventually frustrated by the Comintern's "21 Conditions" which split the USPD and a number of the other Opposition parties. Between 1921 and 1922 this movement centered in the International Working Union of Socialist Parties, the so-called " $2 \frac{1}{2}$ " International. This body actually succeeded for a brief moment in bringing together representatives of the Second and Third "Internationals" during the spring of 1922. Yet by 1923 it had given up any real hope of implementing its ideas and that same year it amalgamated with the resurrected Second International to form the Labor and Socialist International. 
later suggests that it was Josef Herzfeld, a signer of the Adler-Longuet resolution, rather than Eisner or Kautsky who enjoyed the confidence of the majority of Independent Social Democrats. ${ }^{1}$ Under these circumstances it is highly unlikely that Eisner would ever again have exerted an influence in the International like he had at Berne. Even more important is the question of whether Eisner's performance at Berne was not in the long run deleterious to the International. On the one hand Eisner, being unrepresentative of USPD sentiment, was misleading the Conference and weakening the Opposition. On the other hand, without his bridge building the Conference might well have come apart, as he himself suggests. But how great a benefit did the International derive from Eisner's compromises? Were they any more than stop gap measures that set up a façade of unity? Would it not have been better for the Berne Conference to have aired its dirty linen, even at the risk of breaking up? Perhaps the appeal of the artificial construct that appeared in Moscow a few weeks later would not have proven so great had Berne been more representative of its alleged constituency - the politically organized international working class. The behind the scenes work of Kurt Eisner and the low profile adopted by the Opposition moderates were important factors in this development. Had Eisner better reflected the international attitudes of his own party, had the Opposition acted more forcefully, Berne might have been aborted leaving Moscow to live or die on its own merit.

\section{$A P P E N D I X$}

\section{EISNER RESOLUTION I}

Die Konferenz von Bern ist tief von der Ueberzeugung durchdrungen, daß der Sozialismus als Aktion seiner Verwirklichung überall die beherrschende Frage der nächsten Zukunft ist. Damit sich die Entwicklung zur sozialistischen Gesellschaft ohne Hemmungen durchsetze, muß sich das Proletariat jedes Landes einig sein über das Wesen des Sozialismus, über die Mittel des Kampfes und die Formen der Verwirk-

1 Addressing the full Conference on February 10, Kautsky indicated that while Herzfeld opposed the "Branting" resolution both Eisner and himself supported it. Formally, however, Eisner never endorsed the "Branting" resolution. Because of a prior commitment Eisner left the Conference before its conclusion and as late as February 13, he was not aware of the final form the commission resolution had taken on. 
lichung. Die Konferenz fordert darum die Proletariate aller Länder auf, sich organisatorisch und sachlich ein heitlich zusammenzuschließen. Wenn sich die sozialistische Bewegung nicht selbst zerstören soll, so müssen sich die sozialistischen Parteien klar sein über die Probleme der Demokratie und der Diktatur, der Nationalisation und der Sozialisation.

$\mathrm{Zu}$ diesem $Z$ wecke ist es auch notwendig, daß die Versuche einer sozialen Revolution, die in Rußland unternommen worden sind, von Grund aus studiert werden. Darum ist es geboten, daß die Konferenz eine internationale Abordnung nach Rußland entsendet, um eine sachliche Grundlage zu schaffen für die Erörterung und Entscheidung der Probleme auf dem nächsten Internationalen Sozialistischen Kongreß. Indem die Berner Konferenz dermaßen die Fragen des Bolschewismus auf die Tagesordnung des nächsten internationalen! Kongresses gesetzt zu sehen wünscht, warnt sie die bürgerlichen Regierungen, die den Völkerbund begründen wollen, den Bolschewismus als Schreckgespenst $\mathrm{zu}$ verwenden, um die Friedensverhandlungen reaktionärimperialistisch zu beeinflussen und zu entscheiden. Die Welt ist auf dem Wege des Sozialismus und es würde nur eine Zerrüttung aller Verhältnisse bewirken, wenn die kapitalistischen Regierungen versuchen würden, die notwendige und unaufhaltsame Entwicklung des Sozialismus konterrevolutionär zu verhindern.

Arbeiter-Zeitung (Vienna), No 52, February 22, 1919

EISNER RESOLUTION II

Die Berner Sozialistenkonferenz begrüßt in den politischen Revolutionen, die in Europa die allgemeine Demokratie hergestellt haben, den Beginn einer neuen Zeit, in der sich die sozialistische Umgestaltung der Gesellschaft vollziehen wird.

\section{OTHER RESOLUTIONS}

La conférence de Berne exprime sa satisfaction profonde que les révolutions de Russie, d'Allemagne et d'Autriche-Hongrie aient renversé les anciens gouvernements impérialistes et militaristes. Elle fait appel au prolétariat de ces pays pour assurer, à la place de ces gouvernements ruinés, une démocratie inspirée des principes politiques et économiques du socialisme et de la liberté. MacDonald (Renaudel, L'Internationale, p. 127) 
In diesem entscheidenden $\mathrm{Au}-$ genblick, da das Problem des Sozialismus unmittelbar gestellt ist, muß sich das Proletariat einheitlich klar sein über den Weg, den es zu seiner Befreiung beschreiten will.

Die Eroberung der politischen Macht durch das Proletariat ist die Voraussetzung jeder sozialistischen Politik. In dem allgemeinen Wahlrecht, im Parlament, in den politischen Freiheiten der Rede und Schrift, der Versammlung und Koalition, in den Berufsorganisationen besitzt das Proletariat die demokratischen Werkzeuge seines Kampfes. Wenn auch die Macht revolutionär durch eine Minderheit errungen werden kann, so läßt sich eine solche vorübergehende politische Diktatur des Proletariats nur dann behaupten, wenn hinter ihr in Wahrheit eine rasch sich sammelnde Mehrheit steht; um so gefährlicher wäre jeder Versuch einer Diktatur, die sich nur auf einen Teil des Proletariats stützt und sich gegen große Massen derselben zu behaupten übernimmt. Das könnte nur zur Aufreibung des Proletariats im Bruderkrieg und schlieBlich zur Diktatur der Bourgeoisie führen.

Wie die Gesellschaft durch die Demokratie politisch herrscht, so kann auch die Sozialisierung der Produktion nur durch die demokratische Gesellschaft erfolgen, die in aufbauender Arbeit die Umwandlung der Wirt-
Eisner I, first paragraph

Die Konferenz erkennt an die von der Demokratie erfochtenen und entwickelten Grundsätze der persönlichen Freiheit, der Meinungsfreiheit, der Vereins-, Versammlungs- und Pressfreiheit, sowie des Parlamentarismus als unverrückbare Grundlage jeder sozialdemokratischen Politik [...] Wels (Branting Collection)

En outre, la Conférence, renouvelant la déclaration des conférences internationales précédentes disant que la politique du socialisme est fondée sur les principes démocratiques [...] MacDonald (ibid.) 
schaft planvoll entwickelt, nicht aber durch die willkürliche Uebernahme einzelner Betriebe seitens der in ihnen arbeitenden Proletarier.

Die Berner Konferenz hält es für notwendig, unverzüglich eine Untersuchungskommission nach Rußland zu entsenden, um die Wirkungen der dort angewendeten Methoden des politischen Klassenkampfes festzustellen.

Arbeiter-Zeitung (Vienna), No 52, February 22, 1919
Die Konferenz fordert die Vergesellschaftlichung der Produktion und die Besitzergreifung der Staatsgewalt durch die Arbeiterklasse auf Grundlage der Demokratie [...] Wels (ibid.)

[...] elle recommande, pour la réalisation et la stabilité du régime socialiste, la pratique des institutions démocratiques qui prennent leur source dans le suffrage universel. [...]

La Conférence, affirmant le caractère constructif du socialisme, ne sépare pas la Révolution du développement de la production, et écarte les méthodes systématiquement destructives. Renaudel (Renaudel, p. 128)

Eisner I, second paragraph

Elle chargera une commission de les examiner et d'étudier les principes théoriques sur lesquelles ils [the Soviet system] se basent, afin de présenter un rapport à la prochaine réunion de l'Internationale. MacDonald (ibid.)

La Conférence $[\ldots]$ décide qu'une commission socialiste et ouvrière internationaliste sera chargée, dans le plus bref délai possible, d'aller se procurer sur place toutes les données de fait qui, seules, peuvent permettre à l'Internationale de porter sur l'œuvre et les méthodes inaugurées par la Révolution russe un jugement éclairé et définitif. Longuet (Renaudel, p. 132) 


\section{COMMISSION OR "BRANTING" RESOLUTION"}

The Conference hails the great political revolutions which, in Russia, Austria-Hungary and Germany, have destroyed the old régimes of imperialism and militarism and overthrown their Governments. [MacDonald and Eisner II]

The Conference urges the workers and Socialists of these countries to develop democratic and republican institutions which will enable them to bring about the great Socialist transformation. In these momentous times, when the problem of the Socialist reconstruction of the world is more than ever before a burning question, the working classes should make up their minds, unanimously and unmistakably, about the method of their emancipation. [MacDonald and Eisner II]

In full agreement with all previous Congresses of the International, the Berne Conference firmly adheres to the principles of Democracy. A reorganized society more and more permeated with Socialism, cannot be realized, much less permanently established, unless it rests upon triumphs of Democracy and is rooted in the principles of liberty. [Expansion of MacDonald]

Those institutions which constitute Democracy - freedom of speech and of the press, the right of assembly, universal suffrage, a government responsible to Parliament, with arrangements guaranteeing popular cooperation and respect for the wishes of the people, the right of association, etc. - these also provide the working classes with the means of carrying on the class struggle. [Eisner II]

Owing to certain recent events, the Conference desires to make absolutely clear the constructive character of the Socialist programme. True socialisation implies methodical development in the different branches of economic activity under the control of the democracy. The arbitrary taking over of a few concerns by small groups of workers is not Socialism, it is merely Capitalism with numerous shareholders. [Renaudel and Eisner II]

Since, in the opinion of the Conference, effective Socialist development is only possible under democratic law, it is essential to eliminate at once any method of socialisation which has no prospect of gaining

The probable source or sources for each paragraph are indicated in brackets. Although I have not seen a copy of Branting's original proposal, it seems highly likely that, based on Branting's comments during the Conference as well as the fact that paragraphs six and twelve lack any clear relationship to any of the other four original proposals, Branting's original proposal probably served as the basis for these particular sections. 
the support of the majority of the people. [Branting?]

A dictatorship of this character would be all the more dangerous if it were based upon the support of only one section of the working class. The inevitable consequence of such a regime would be the paralysis of working-class strength through fratricidal war. The inevitable end would be the dictatorship of reaction. [Eisner II]

The Russian delegates have proposed that a commission composed of representatives of all Socialist tendencies should be appointed by the Conference to visit Russia for the purpose of making an impartial report to the International on the political and economic situation there. The Conference fully realises the difficulties involved in such a task; nevertheless, considering the general interest Socialists of all countries have in exact knowledge of the facts bearing on these popular upheavals, the Conference authorises the permanent Commission to arrange for a delegation to be sent to Russia on this mission. [MacDonald and Eisner II]

The Conference decides to put the question of Bolshevism on the agenda of the next Conference, and recommends the permanent Commission to carry out the necessary preparatory work. [Eisner I]

The Conference, however, desires to call immediate attention to the fact that the famine and misery which the war has brought to the whole world, and more especially to the defeated countries, was bound to lead to social disorganisation. [Renaudel]

Instead of using Bolshevism as a bogey and denouncing under this term every revolt of working people reduced to the lowest depths of despair, Governments should face their own responsibilities. Counterrevolutionary forces are already at work everywhere. The Conference warns those who now hold the fate of the world in their hands, against the dangers of an imperialistic policy, and of a policy of military or economic enslavement of the peoples. [Modification of Eisner I]

It calls upon Socialists throughout the world to close their ranks, not to deliver up the peoples to international reaction, but to do their utmost to ensure that Socialism and Democracy, which are inseparable, shall triumph everywhere. [Branting?]

International Labour and Peace, p. 6

ADLER-LONGUET RESOLUTION

The leading idea of the policy which we have resolutely and tirelessly pursued throughout the whole course of the war, was the reconstitution 
of the international front of the conscious revolutionary proletariat. This same fundamental principle also determined our attitude towards the Berne Conference.

We maintain that this Conference runs the risk of provoking grave criticism, not because of what is contained in its resolutions, but because certain commonplace truths have been expressed too late, not during the war, but after the war is over.

On the other hand, the resolution on Democracy and Dictatorship gives cause for most serious objections. The same men who have passively or actively hindered international action for four and a half years, who have thought it their duty to abstain from any international meeting, now eagerly utilise the Conference for a course of action which will inevitably increase the difficulties of the International.

We warn the working classes against any kind of stigma which may be applied to the Russian Soviet Republic. We have not sufficient material for a judgment. One thing only we do know with certainty, that the shameful campaign of lying, in which the press and agencies of the Central Empires and Entente have competed with each other during the war, continues unchanged to-day.

We do not wish, by passing premature judgment on political methods, to be the victims of the manoeuvres and interested calumnies of bourgeois governments. To our great regret, we are unable to rely solely on the information received from those Russian delegates present at the Conference, who represent only a minority of the Russian working class. We do not cast the slightest doubt on their good faith, but we must demand that the International remain true to its old principle of hearing both sides before coming to a decision. The Berne Conference is but a first feeble attempt at an international assembly. Whole parties, such as the Italian, Serbian, Roumanian, and Swiss are standing aside! Others are taking part reluctantly.

We have warned you against any decision which would make the meeting of the working classes of all countries more difficult in the future. We desire to reserve free entry into the International for the Socialist and Revolutionary Parties of all countries conscious of their class interests.

The majority of the Commission have not listened to our warnings. We do not wish to be parties to any action against the International and we cannot be bound by the resolution as a whole, since certain paragraphs can be exploited by the bourgeoisie.

International Labour and Peace, p. 7 